\title{
A "Treasury perspective" of GP Charter
}

\author{
RUDOLF KLEIN
}

The following document has fallen into my hands. It seems to be the draft of a Treasury memorandum to the Cabinet on the report of the GP Charter Working Group. ${ }^{1}$ Because of its interest to members of the medical profession, as an indication of the Government's likely response to this initiative, I reproduce it here.

\section{Two main aims}

The report of the GP Charter Working Group raises several major issues of principle for the management of public expenditure and for the management of the National Health Service. It is likely to remain a subject of controversy and debate between the profession and the Government for some time to come. This paper therefore explores some of the implications of these proposals. In particular, it analyses what seem to be the two main aims of the document and asks to what extent they are compatible with each other. We have interpreted the two aims as follows. Firstly, to improve the quality of the service provided by increasing the number of general practitioners and by introducing several financial incentives designed to encourage good practices and adequate support for GPs, and the return of some medical care from the expensive hospital sector to the community. This might be called the professional objective of the report. Secondly, to replace the present system of general practitioner remuneration-which essentially represents a fixed financial commitment-by one which allows GPs more scope to determine their own earnings by introducing more item-ofservice payments. This might be called the trade union objective of the report.

We look at the financial implications first. A major issue of principle raised by these proposals is whether or not they are compatible with the need to control public expenditure. If public expenditure planning is to be effective, it is essential to avoid open-ended financial commitments-that is, commitments whose cost cannot be predicted, since they are determined by either service producers or service consumers. Indeed, the strength of the NHS, in contrast to the health care systems of most other countries, has always lain in the fact that it can do precisely this-that is, it works to a fixed budget. There are exceptions-for example, the pharmaceutical services and the item-of-service payments to GPs which have already been introduced. The proposals of the new GP charter document would, however, appear to challenge the fixed budget principle more fundamentally. The changes would allow GPs more scope to determine their own earnings and would weaken the ability of governments to impose a predetermined ceiling on expenditure. Additionally, the proposed system would increase the NHS's administrative costs. Multiplying item-of-service payments inevitably means more bureaucracy and paper work (not least for the doctors themselves).

This conclusion might suggest that the Government should reject the proposals out of hand on grounds of principle. In practice, however, the proposals may not be as financially

\section{University of Bath}

RUDOLF KLEIN, MA, professor of social policy threatening as they seem. The example of the dentists may suggest that even a fee-for-service system is compatible with strict financial control. Historically, this shows that it is politically feasible to reduce a fee scale if it gets out of hand: indeed, as the Guillebaud report showed, ${ }^{2}$ the cost of the dental services fell in the 'fifties after the boom of the late 'forties. At present, to judge from the attitude of the Review Body, ${ }^{3}$ it would seem more accurate to say that the level of fees is determined by judgments about what the total remuneration of dentists should be than to say that total earnings are determined by the level of fees and the amount of work done. Admittedly the case of the junior hospital doctors suggest that it is possible to gain dramatic increases in earnings by introducing special items of payment related to work load. But in this particular instance the Treasury and the health authorities were caught napping. The consequences of introducing these special payments were not accurately foreseen. We have learnt our lesson.

Conceivably the economic climate may improve and allow more money to be put into the NHS, though we are pessimistic about this. Possibly, too, future governments may be more prepared to increase taxes, though once again we are sceptical. In the absence of such a fundamental change, any extra remuneration for GPs-or any other NHS staff-will have to be paid for out of the already committed resources-that is, there will have to be compensatory economies. The Government should therefore explain that in the present circumstances attempting to improve the level of earnings and seeking to increase the number of GPs are to a large extent alternative, not complementary, strategies.

To sum up, if the aim of the profession is simply to change the methods of remuneration-that is, to redistribute earnings within the family practitioner service to give more to those GPs who work hardest-then we seen no reason, on grounds of public policy, for opposing such a change. If, however, there is to be any increase in the total allocation of spending to the NHS, over and above what is envisaged in the current Expenditure White Paper, ${ }^{4}$ then this ought to be the result of an explicit political decision by ministers to change their priorities-not the by product of a new agreement on the structure of remuneration. The arguments for changing the structure and for changing the level of remuneration are logically distinct and should not be confused.

\section{Level of GP earnings}

This brings the argument to another issue of principle raised by the new GP Charter. Is the level of GP earnings inadequate? As ministers will be aware, this question raises the general-and currently explosive-issue of public sector pay levels. In the case of the medical profession, however, it is the specific function of the Review Body to ensure that medical earnings keep in line with those of other comparable professions: the principle established by the 1960 Royal Commission. ${ }^{5}$ The discontent of the medical profession therefore reflects not the lack of machinery for determining fair relativities but the fact that the incomes policies of successive governments have not allowed the machinery to function in the way intended. In this respect, the attitude of the medical profession mirrors that of many trade 
unions representing skilled workers, whose differentials have been eroded. In turn, this might suggest that future incomes policies should not attempt to compress the distribution of earnings: a counterproductive strategy, on past experience.

Instead, it might perhaps be recognised that the proper instruments for changing the distribution of income are the tax system and such social security payments as child benefits. In the case of the medical profession, the level of taxation is probably as much a cause of discontent as the level of earnings. Indeed, if the Government's concern continues to be to achieve a greater equality in post-tax incomes-the trend in recent years ${ }^{6}$ - then the logic of conceding higher earnings for professionals is higher income taxes. If the Government, however, was prepared to abandon this objective cutting income tax might be a way of defusing the demands for higher pay.

But the other cause of medical discontent-the comparisons made in the GP Charter between the level of earnings in Britain and in other EEC countries-raises different issues. In part, these differences reflect the fact that most EEC countries are much wealthier than Britain. Logically there is therefore no reason to expect the incomes of British doctors to match those of their European counterparts. But the earnings of British doctors are also relatively lower. Thus average medical incomes in this country represent a multiple of 2.7 of average male manual earnings, while the equivalent figures for France and Germany are respectively $7 \cdot 0$ and $6 \cdot 1$.

This raises the crucial question of whether Britain's EEC membership, and the consequent right of doctors to move across frontiers, is incompatible with such differentials in rewards. The assumption of the GP Charter is that, unless British standards of rewards move in the direction of Europe, British doctors will move in the direction of Europe. This is debatable, and there are two main reasons for scepticism. Firstly, most of the EEC countries not only have more doctors per population than Britain but are also training proportionately more ${ }^{8}$ Many of them-notably Italy, France, and Germanyface an imminent crisis of overproduction. Secondly, and linked to this, the response of many European governments to an ever-increasing number of doctors-each of whom generates extra demands on resources by his activities-is to impose stricter finnancial controls on total outgoings. In the case of France, for example, the rise in payments per item of service in the period 1962 to 1975 lagged considerably behind the increase in salaries generally, and doctors were able to maintain their incomes only by working longer hours, thus showing that such a system of payments may become a professional treadmill. ${ }^{9}$ Indeed, the underlying trend in France seems to be towards a salaried system. It would therefore be ironical if Britain were to move towards an item-of-service system just at a time when the EEC countries were beginning to move in the reverse direction.

\section{Doubtful prop}

The European experience therefore provides a doubtful prop for the argument in favour of adopting an item-of-service system in this country. As to the other theme of this paper, however, such a system may still be justified not so much as a trade union strategy for increasing medical incomes as a professional strategy for enhancing the quality of service provided. The weakness of the present British system is that it provides no direct financial incentives for good practice. If anything, it might specifically be designed to encourage general practitioners to offload their most difficult or troublesome patients on to the more expensive hospital system. A system of payments which reverses this balance might therefore be attractive in terms of minimising the total cost of health care and making the most economic use of the available resources. To the extent that the proposals of the GP Charter would enhance the position of the primary care sector, and relieve the burden on the hospital sector, they deserve careful consideration by the Government.

How far do the specific proposals of the GP Charter promise to bring about such a state of affairs ? In the past when item-ofservice payments have been introduced these have been designed to provide incentives to supply services judged to be desirable. In other words there has been an explicit policy decision that it is worth spending public money to achieve certain aims-such as better family planning or immunisation services. But looking at appendix B of the GP Charter-which lists acts which might qualify for item-of-service payments-the logic of the selection is not self-evident. Is it really desirable to provide financial incentives to encourage ear syringing or wart cautery ? We are not, of course, qualified to make any judgment on the medical desirability, or otherwise, of such acts. We look forward to getting the advice of the medical staff of the DHSS on this point. In our view, however, the only justification for spending extra money on item-of-service payments is that the result will be to produce services which are desirable in themselves and which are not already being performed, or are being carried out expensively in hospital when they could be done more economically in general practice. We question the value of introducing incentive payments which simply give extra rewards to doctors for what they are or ought to be doing already.

This said, we believe that it would be a mistake for the Government to reject outright the idea of introducing item-ofservice payments. We believe that selective financial incentives could improve the provision and use of resources in the NHS, subject to two caveats. Firstly, financial incentives should be provided only for those acts where there is a demonstrable effect in terms of either preventing illness or offering treatment which would otherwise have to be provided in hospital. Secondly, there should be adequate safeguards against the distortions that may be caused by incentive payments. To take a no doubt absurd example, if doctors were to decide to increase their earnings by syringing the ears of all their patients, the result would hardly improve the nation's health and might divert them from other, more useful professional activities.

\section{Audit}

If the medical profession were to agree to adequate safeguards the GP Charter might give the DHSS an opportunity to do something which it has hitherto been entirely unable to achieve. So far Britain's GPs have had a virtually total immunity from administrative control because there has been an almost total lack of information about what they do. But information follows money. It is no accident that there is more administrative control over practitioners in Germany, France, the United States, and other countries where there are item-of-service payments. The GP Charter recognises this, when it points out that the collection of data flowing from item-of-service payments would permit an audit of general practice.

But an audit based simply on such very limited financial information could be misleading, giving only a partial view of what was happening. It would not, for example, permit any analysis of the displacement effect of incentives-that is, an analysis of what was not being done, as well as of what was being done. The logic of medical audit is surely to base it on a comprehensive information system, which would, for instance, have to include data about referral patterns and about whether or not special at-risk population groups (such as the elderly) were being seen regularly. The other problem about the approach suggested by the GP Charter stems from the suggestion that the audit should be carried out by the local medical committee. This would, surely, impose a heavy burden on the LMC. One of the reasons why medical audit is still more of an aspiration than a reality is that it presents formidable methodological and conceptual problems. It is not self-evident that LMCs have either the staff or the skill required for such a difficult exercise. Furthermore, while such a self-audit by LMCs would undoubtedly improve the quality of practice even further in those areas where it is already high, it might perpetuate lower standards in those areas where there is now cause for concern. 
The example of the hospital sector underlines the paradox that it is the doctors of the highest calibre who have pioneered methods of audit, while the institutions which most need critical self-examination are least likely to engage in such a review. We see the answer as being a national audit service, independent of both the DHSS and of local professional interests, though we realise that doctors would probably resist such a proposal with vigour.

The conclusion from this analysis is that the Government would do well to give a cautious welcome to the GP Charter as a negotiable package. The medical profession could obtain direct incentives to greater efforts. In return, the community could benefit from a more effective use of health resources and from a clear commitment by GPs to audit.

\section{References}

${ }^{1}$ British Medical fournal, 1979, 1, 564.

2 Report of the Committee of Enquiry into the Cost of the National Health Service, Cmnd 9663. London, HMSO, 1956.

3 Review Body on Doctors' and Dentists' Remuneration, Eighth Report, Cmnd 7176. London, HMSO, 1978.

4 The Government's Expenditure Plans 1979-80 to 1982-83, Cmnd 7439. London, HMSO, 1979.

${ }^{5}$ Royal Commission on Doctors' and Dentists' Remuneration, Report, Cmnd 939. London, HMSO, 1960. Cmnd 6999. London, HMSO, 1977.

7 Public Expenditure on Health, OECD Studies in Resource Allocation. Paris, 1977.

${ }^{8}$ DHSS, Medical Manpower-the next twenty years. London, HMSO, 1978.

9 Stephan, Jean-Claude, Economie et Pouvoir Médical. Paris, Economica, 1978.
${ }^{6}$ Royal Commission on the Distribution of Income and Wealth, Report No 5 ,

\section{Pay-beds in the NHS: proposed reductions}

The Health Services Board has issued provisional proposals for phasing out further pay-beds from NHS hospitals in 1979. These are set out here.

Consultative proposals for the revocation of pay-bed authorisations issued by the Health Services Board on 20 February 1979

\begin{tabular}{|c|c|c|c|c|}
\hline $\begin{array}{l}\text { Private nursing home or } \\
\text { hospital whose spare capacity } \\
\text { is the basis of the board's } \\
\text { consultative proposals }\end{array}$ & $\begin{array}{l}\text { Area health authority and } \\
\text { authorised hospitals which } \\
\text { are the subject of the board's } \\
\text { consultative proposals }\end{array}$ & $\begin{array}{c}\text { Size of } \\
\text { existing } \\
\text { authorisation } \\
\text { (number of } \\
\text { beds) }\end{array}$ & $\begin{array}{l}\text { Reduction } \\
\text { provisionally } \\
\text { proposed } \\
\text { (number of } \\
\text { beds) }\end{array}$ & $\begin{array}{l}\text { Number of } \\
\text { pay-beds } \\
\text { remaining if } \\
\text { proposals } \\
\text { took effect }\end{array}$ \\
\hline \multirow{6}{*}{$\begin{array}{l}\text { St Mary's Nursing Home, } \\
\text { Ednaston, } \\
\text { Derby }\end{array}$} & $\begin{array}{l}\text { Derbyshire AHA } \\
\text { Central Derbyshire Health } \\
\text { District Group } \\
\text { Derbyshire Hospital for }\end{array}$ & 3 & 1 & 2 \\
\hline & $\begin{array}{l}\text { Women } \\
\text { South Derbyshire HD Group } \\
\text { Derbyshire Royal Infirmary }\end{array}$ & $\begin{array}{r}3 \\
15 \\
15\end{array}$ & $\begin{array}{l}1 \\
7 \\
7\end{array}$ & $\begin{array}{l}2 \\
8 \\
8\end{array}$ \\
\hline & $\begin{array}{l}\text { or } \\
\text { Central and South Derbyshire } \\
\text { HDs }\end{array}$ & 18 & 8 & $\begin{array}{l}10 \text { (new } \\
\text { combined } \\
\text { grouping) }\end{array}$ \\
\hline & $\begin{array}{l}\text { Derbyshire Hospital for } \\
\text { Women }\end{array}$ & 3 & - & 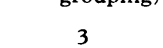 \\
\hline & $\begin{array}{l}\text { Derbyshire Royal Infirmary } \\
\text { Derby City Hospital } \\
\text { Bretby Hall }\end{array}$ & $\begin{array}{r}3 \\
15\end{array}$ & $\frac{5}{-}$ & $\begin{aligned} 10 \\
1\end{aligned}$ \\
\hline & Orthopaedic Hospital & 2 & - & 2 \\
\hline \multirow[t]{2}{*}{$\begin{array}{l}\text { St Joseph's Hospital, } \\
\text { Mount Street, } \\
\text { Preston }\end{array}$} & $\begin{array}{l}\text { Lancashire AHA } \\
\text { Preston HD Group } \\
\text { Preston Royal Infirmary } \\
\text { Sharoe Green Hospital } \\
\text { or }\end{array}$ & $\begin{array}{l}4 \\
4 \\
3\end{array}$ & $\begin{array}{l}3 \\
3 \\
2\end{array}$ & $\begin{array}{l}1 \\
1 \\
1\end{array}$ \\
\hline & Preston and Ormskirk HDs & 15 & 5 & $\begin{array}{l}10 \text { (new } \\
\text { combined } \\
\text { grouping) }\end{array}$ \\
\hline \multirow{3}{*}{$\begin{array}{l}\text { Park House Nu } \\
\text { Home, } \\
\text { Haigh Road, } \\
\text { Waterloo, } \\
\text { Liverpool }\end{array}$} & Preston Royal Infirmary & 4 & 3 & 1 \\
\hline & $\begin{array}{l}\text { Sharoe Green Hospital } \\
\text { Ormskirk and District }\end{array}$ & 3 & 2 & 1 \\
\hline & $\begin{array}{l}\text { Hospital } \\
\text { Wrightington Hospital }\end{array}$ & $\begin{array}{l}4 \\
8\end{array}$ & 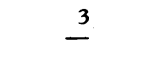 & $\begin{array}{l}1 \\
8\end{array}$ \\
\hline $\begin{array}{l}\text { Holly House Private Hospital, } \\
\text { High Road, } \\
\text { Buckhurst Hill, } \\
\text { Essex }\end{array}$ & $\begin{array}{l}\text { Redbridge and Waltham } \\
\text { Forest AHA } \\
\text { East Roding HD } \\
\text { West Roding HD }\end{array}$ & $\begin{array}{l}7 \\
8\end{array}$ & $\begin{array}{l}7 \\
8\end{array}$ & 二 \\
\hline
\end{tabular}

\section{General Medical Council}

Lord Richardson, the president, was il the chair when the General Medical Council met on 21 February. The succession day for the reconstituted GMC would be 27 September 1979, he said. There would be 50 elected members, 34 appointed, and not more than 11 nominated members. Elected members would hold office for five years and nominated members for not more than five years.

Sir Robert Wright presented the report of the Overseas Committee and pointed out that there were 1500 fewer overseas doctors on the temporary register than a year ago. Dr Michael

\section{Normansfield}

As a result of disciplinary hearings by Kingston and Richmond AHA following the recommendations of the Sherrard Committee of Inquiry into Normansfield Hospital (2 December 1978, p 1560) Mr Rawlings has been told that he can remain divisional nursing officer in the authority but have no responsibility for Normansfield. The senior nursing officer, Mr D McCann, is to be downgraded to nursing officer and transferred to another hospital. The Sherrard Report had recommended that their appointments should be terminated and they should not be reemployed at Normansfield in any capacity.

The nursing officer, $\mathrm{Mr} \mathrm{D}$ Cumming, is to be found a new post in another hospital and has been given a written warning about his conduct. Mr R Restel, nursing officer, is to be downgraded and found another post. The report had recommended the termination of their employment.

Mr W Taylor, area administrator, will remain in post but has received a written warning about his conduct. The report had recommended that he should be dismissed but members of the authority thought that he should not be singled out for disciplinary action. He was not the chief officer of the area management team.

The area medical officer, Dr Alastair Nelson, will face a disciplinary hearing shortly.

\section{Nottingham Scientific Meeting}

'Donnell said that he was concerned that the council was modifying the experience required for working in accident departments. He hoped that the council would keep an eye on this and if the new arrangements were unsatisfactory would consider reimposing the more stringent requirements. Sir Robert agreed that there had been fewer complaints about people holding posts in accident and emergency since the previous restrictions had been introduced. He gave an assurance that the Overseas Committee would monitor the problem.

The programme for the Annual Scientific Meeting in Nottingham, 5 to 7 April, was published on 25 November 1978, p 1512. The title of the Boots Lecture by Dr Barbara Ansel on 7 April has been changed to "Drug therapy in rheumatoid arthritis." The subject of Professor R E Cotton's paper, during the "Cancer screening" session, also on 7 April, will be "Cervical cytology 1962-79: changes in emphasis relevant to alterations in social

\section{AHA disciplinary hearings} habits and the efficacy of screening." 